\title{
Future Directions for K-12 Technology-Enhanced Learning Environments
}

\author{
Drew Polly ${ }^{1} \cdot$ Erik J. Byker $^{1} \cdot$ Madelyn W. Colonnese ${ }^{1}$ \\ Published online: 30 March 2021 \\ (C) Association for Educational Communications \& Technology 2021
}

\section{Overview}

When we submitted our proposal to edit a Special Issue of Tech Trends on technology-enhanced learning environments in classrooms from Kindergarten through Grades 12 (K-12) two years ago we, like everyone else, had no idea what the past 15 months would have looked like due to the COVID-19 pandemic. Educators have responded heroically - quickly entering emergency teaching mode - designing asynchronous, synchronous, and bichronous learning experiences (Martin et al. 2020) for their students. Numerous digital technologies have supported their work in multiple ways. By drastically changing the way the majority of instruction is delivered, teachers, curriculum developers, and educational leaders have been creative, innovative, and flexible. It is likely that our own personal experiences over the past two years have provided examples of the affordances that technology can have on supporting teaching and learning. And as a result, one may read the following contributions with a new perspective. It is important to note that due to the initial timeline of submissions this special issue is not focused on how technology enhanced teaching and learning during COVID-19.

Technology can support teaching and learning. However, it must be carefully examined to understand the extent to how it should be used with learners in K-12 contexts and learning environments (International Society for Technology in Education [ISTE], 2016; Ross 2020). We open the special issue with specific thoughts that we hope will be helpful to readers.

Drew Polly

abpolly@uncc.edu

Erik J. Byker

ebyker@uncc.edu

Madelyn W. Colonnese

mcolonn1@uncc.edu

1 University of North Carolina at Charlotte, Charlotte, NC, USA

\section{Advancing Scholarship of Technology-Enhanced Learning Environments}

Scholars have clearly indicated that technology is most effective when it provides students with opportunities to engage in activities focused on higher-order thinking - thinking that goes beyond simple drill and practice activities (Freeman et al. 2017; Ross 2020). Currently, new devices and technology-specific activities are being created and infused into K-12 contexts. To measure the effectiveness of these new technologies, there is a need for an examination of the influence of the technologies on teaching and learning. Ross (2020) recommended evaluation and research studies to investigate the interplay between technologies, teaching, and learning in various forms, including one-shot approaches to data collection as well as more longitudinal studies that examine teaching and learning with technology over time.

Further, there is a need for data collection to be more robust and to examine technology infusion efforts within a myriad of data sources. Guskey (2002) proposed a multilevel framework to evaluate work with K-12 teachers. This framework has also been used to examine pre-service teachers (Polly 2017). Data collection focuses on the levels of: (1) participants' (teachers and students) reactions to their experiences, (2) evidence of teachers' knowledge of skills on formal assessments, (3) applications of teachers' knowledge and skills on projects and contextualized experiences, (4) impact on the organization or systems, and (5) impact on K-12 student learning. Such levels of data collection can allow for multiple perspectives and experiences. While it may not be practical to collect data from multiple levels in each study, researchers should take into account these levels as they consider the design of their study and the implications for their work. Frameworks such as Guskey's (2002) can also provide insight for more novel scholarship. Currently, the knowledge base lacks studies that examine levels 4 and 5. 


\section{Supporting Teachers' Capacity to Teach with Technology}

Pre-service teachers and in-service teachers do not magically learn how to effectively teach with technology without focusing on specific related processes (Kopcha et al. 2020). There is a need for both pre-service teachers and in-service teachers to see exemplars modeled for them (Polly et al. 2020; Tondeur et al. 2017) as well as have authentic opportunities to practice with support in low-risk environments (Tondeur et al. 2011, 2017). Modeling combined with opportunities for practice provides a "technological apprenticeship of observation" (Byker et al. 2018, p. 135) about what purposeful technology integration entails as well as the affordances and constraints of the technology integration. Additionally, such technological apprenticeship in teaching and learning should be supported by a framework to encourage play and discovery of the instructional technologies' possibilities for classroom integration. In this regard, Technological Play Theory (Byker 2016) provides an instructive framework for illustrating how technological apprenticeship supports the movement of curiosity to creativity while using technological tools. Technological play can support and expand the capacity of pre-service teachers and in-service teachers to utilize instructional technology for effective outcomes.

During COVID-19 teachers created and leaned heavily on their personalized learning network on social media,YouTube (Martin et al., in press), district curriculum guides, and/or online support from commercial curriculums, to find examples about how to use technology to deliver instruction and to enhance instruction. In our state, district mathematics coach Dawne Coker transformed her YouTube channel from one with videos explaining mathematics concepts to teachers, into one where she recorded and posted virtual lessons using costumes and visuals to make mathematics come to life (Coker n.d.). Because of the wide variety of ways that teachers informally constructed knowledge and developed skills related to using technology to support instruction, there is a need to examine many aspects of both teaching and learning such as resources teachers relied upon, the practices teachers found effective, and the impact on student learning.

Lastly, various constructs and models have been advanced as ways to conceptualize teachers' use of technology and how teachers learn to integrate technology with instructional content and pedagogy. The Technological Pedagogical Content Knowledge (TPACK) framework offers a comprehensive way to frame efforts aimed at developing the knowledge and skills related to technology integration (Mishra \& Koehler 2006). It has become widely used around the world and has led to the development of instruments and methodologies used to research and examine topics such as the TPACK individuals report on surveys (Byker et al. 2018; Clausen et al. 2019; Schmidt et al. 2009) or demonstrate on lesson plans or episodes of teaching (Cox and Graham 2009; Polly 2019; Urbina and Polly 2017; Polly 2011). TPACK provides a neutral unbiased way of examining teachers' knowledge and skills related to teaching with technology without privileging specific learning theories or instructional practices (Mishra \& Koehler 2006). While it has been widely used, some have cited skepticism about the TPACK framework (BrantleyDias and Ertmer 2013; Kopcha et al. 2014). Regardless of the framework or model that is used to design, implement, and evaluate efforts to support teachers there is a need for these frameworks and models to be empirically grounded.

\section{Broadening our Audience and Impact}

One of the things that we have realized and have come to rely on during COVID-19 was our need to collaborate and share expertise with one another. At our university and in our partner schools, those who regularly used technology before the pandemic, shared their expertise with those who had less experience teaching with technology. Others who had expertise in the content areas (e.g, literacy, mathematics, science, social studies) were able to provide suggestions about how to leverage the technology in ways that were specific to a particular discipline. The use of social media, YouTube, and other online resources has helped to bring individuals from different fields together. For example, elementary teachers looking for specific resources and ideas to teach concepts through synchronous, asynchronous, or bichronous approaches may have sought out those with expertise related to teaching with technology.

As Tech Trends is read by people in various roles across the world there is a need for each of us to reconsider how our work intersects with others for the collective common good of enhancing teaching and learning. That need requires us to embrace broad perspectives of the design and research of technology-enhanced learning environments. As Michael Hannafin wrote with colleagues (Hannafin et al. 1997):

Our challenge is to determine the extent to which we are part of and integral to broader education communities, and to evolve our approaches accordingly. To the extent that our perspectives are restricted or rigid, we limit both our capacity to evolve and the breadth of our impact; to the extent that our perspectives broaden, we evolve both in the conceptualization and design of learning systems and the communities we support.

Regardless of your roles as teacher educators, instructional designers, researchers, or administrators Hannafin et al.'s words remind us that we must embrace broad perspectives and consider how we can collaborate with others to enhance teaching and learning. 


\section{References}

Brantley-Dias, L., \& Ertmer, P. A. (2013). Goldilocks and TPACK: Is the construct' just right?'. Journal of Research on Technology in Education, 46(2), 103-128. https://doi.org/10.1080/15391523. 2013.10782615.

Byker, E. J. (2016). I play I learn: Introducing technological play theory. In D. Polly \& C. Martin (Eds.), Handbook of research on teacher education and professional development. IGI Global: Hershey.

Byker, E. J., Putman, S. M., Handler, L., \& Polly, D. (2018). Examining elementary education teachers and pre-service teachers' selfefficacy related to technological pedagogical and content knowledge (TPACK). In C. Hodges (Ed.), Self-efficacy in instructional technology contexts (pp. 119-140). Springer: New York.

Clausen, J. M., Finsness, E. S., Borthwick, A. C., Graziano, K. J., Carpenter, J. P., \& Herring, M. (2019). TPACK leadership diagnostic tool: Adoption and implementation by teacher education leaders. Journal of Digital Learning in Teacher Education, 35(1), 54-72.

Coker, D. (n.d.). Dawne Coker's YouTube Channel. Retrieved from: h t t p s:// w w w. y o u t u b e. co m/ c han n e 1/ UCyNF0x8kxOsXmcY5fUVlEcw.

Cox, S., \& Graham, C. R. (2009). Diagramming TPACK in practice: Using an elaborated model of the TPACK framework to analyze and depict teacher knowledge. TechTrends., 53(5), 60-69.

Freeman, A., Adams Becker, S., Cummins, M., Davis, A., \& Hall Giesinger, C. (2017). NMC/CoSN horizon report: 2017 K-12 edition. Austin: The New Media Consortium.

Hannafin, M. J., Hannafin, K. M., Land, S. M., \& Oliver, K. (1997). Grounded practice and the design of constructivist learning environments. Educational Technology Research and Development, 45(3), 101-117.

International Society for Technology in Education. (2016). ISTE standards for students: A practical guide for learning with technology. Washington, DC: Author.

Kopcha, T. J., Ottenbreit-Leftwich, A., Jung, J., \& Baser, D. (2014). Examining the TPACK framework through the convergent and discriminant validity of two measures. Computers \& Education, 78, 87-96.

Kopcha, T. J., Neumann, K. L., Ottenbreit-Leftwich, A., \& Pitman, E. (2020). Process over product: The next evolution of our quest for technology integration. Educational Technology Research and Development, 68(1), 1-21.

Martin, F., Polly, D., \& Ritzhaupt, A.D. (2020). Bichronous online learning: Blending asynchronous and synchronous online learning. Educause review. Retrieved from: https://er.educause.edu/articles/ 2020/9/bichronous-online-learning-blending-asynchronous-andsynchronous-online-learning
Mishra, P., \& Koehler, M. J. (2006). Technological pedagogical content knowledge: A framework for teacher knowledge. Teachers College Record, 108, 1017-1054.

Polly, D. (2011). Examining teachers' enactment of technological pedagogical and content knowledge (TPACK) in their mathematics teaching after technology integration professional development. Journal of Computers in Mathematics and Science Teaching, 30(1), 37-59.

Polly, D. (2017). Providing school-based learning in elementary school mathematics: The case of a professional development school partnership. Teacher Development: An International Journal of Teachers' Professional Development, 21(5), 668-686. https://doi. org/10.1080/13664530.2017.1308427.

Polly, D. (2019). Developing TPACK for elementary education teacher candidates in an instructional design and technology integration course. In M. Niess, H. Gillow-Wiles, \& C. Angelia (Eds.), Technological pedagogical content knowledge (TPACK) in the digital age (pp. 329-349). IGI Global: Hershey.

Polly, D., Byker, E. J., Putman, S. M., \& Handler, L. K. (2020). Preparing elementary education teacher candidates to teach with technology: The role of modeling. Journal of Digital Learning in Teacher Education, 36(4), 250-265.

Ross, S. M. (2020). Technology infusion in K-12 classrooms: A retrospective look at three decades of challenges and advancements in research and practice. Educational Technology Research \& Development, 68(5), 2003-2020.

Schmidt, D. A., Baran, E., Thompson, A. D., Mishra, P., Koehler, M. J., \& Shin, T. S. (2009). Technological pedagogical content knowledge (TPACK) the development and validation of an assessment instrument for preservice teachers. Journal of Research on Technology in Education, 42(2), 123-149. https://doi.org/10.1080/15391523. 2009.10782544.

Tondeur, J., Roblin, N. P., van Braak, J., Voogt, J., \& Prestridge, S. (2017). Preparing beginning teachers for technology integration in education: Ready for take-off? Technology, Pedagogy, and Education, 26(2), 157-177. https://doi.org/10.1080/1475939X. 2016.1193556.

Tondeur, J., van Braak, J., Sang, G., Voogt, J., Fisser, P., \& OttenbreitLeftwich, A. (2011). Preparing teacher candidates to integrate technology in education: A synthesis of qualitative evidence. Computers \& Education, 59(1), 134-144. https://doi.org/10.1016/j.compedu. 2011.10.009.

Urbina, A., \& Polly, D. (2017). Examining elementary school teachers' integration of technology and enactment of TPACK in mathematics. International Journal of Information and Learning Technology, 34(5), 439-451. https://doi.org/10.1108/IJILT-06-2017-0054.

Publisher's Note Springer Nature remains neutral with regard to jurisdictional claims in published maps and institutional affiliations. 